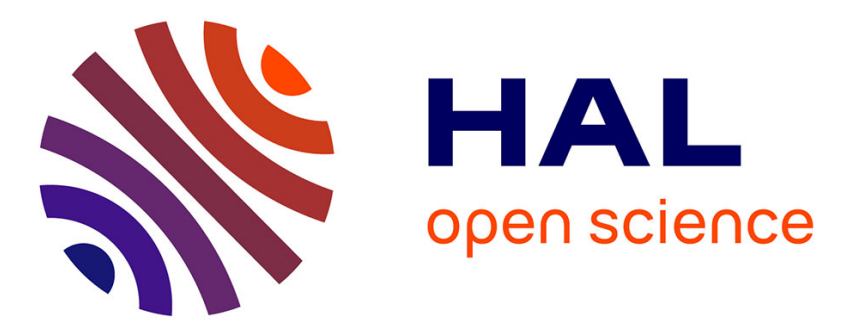

\title{
Geomorphic Variations of Debris Flows and Recent Climatic Change in the French Alps
}

\author{
Vincent Jomelli, V. Pech, C. Chochillon, D. Brunstein
}

\section{To cite this version:}

Vincent Jomelli, V. Pech, C. Chochillon, D. Brunstein. Geomorphic Variations of Debris Flows and Recent Climatic Change in the French Alps. Climatic Change, 2004, 64 (1/2), pp.77-102. 10.1023/B:CLIM.0000024700.35154.44 . hal-03037003

\section{HAL Id: hal-03037003 https://hal.science/hal-03037003}

Submitted on 4 Dec 2020

HAL is a multi-disciplinary open access archive for the deposit and dissemination of scientific research documents, whether they are published or not. The documents may come from teaching and research institutions in France or abroad, or from public or private research centers.
L'archive ouverte pluridisciplinaire HAL, est destinée au dépôt et à la diffusion de documents scientifiques de niveau recherche, publiés ou non, émanant des établissements d'enseignement et de recherche français ou étrangers, des laboratoires publics ou privés. 


\title{
GEOMORPHIC VARIATIONS OF DEBRIS FLOWS AND RECENT CLIMATIC CHANGE IN THE FRENCH ALPS
}

\author{
V. JOMELLI ${ }^{1}$, V. P. PECH ${ }^{1,2}$, C. CHOCHILLON ${ }^{1,2}$ and D. BRUNSTEIN ${ }^{1}$ \\ ${ }^{1}$ CNRS, UMR 8591 Laboratoire de Geographie Physique, 1 place A. Briand, \\ 92195 Meudon-Bellevue, France \\ E-mail:Jomelli@cnrs-bellevue.fr \\ ${ }^{2}$ Université Paris 1 Panthéon-Sorbonne, 191 rue Saint Jacques, 75005 Paris, France \\ E-mail:pech@univ-paris1.fr
}

\begin{abstract}
Much work has been done to show that there is a relationship between the triggering of debris flows and the recorded increase in temperatures or in the number of intense rainy events over the last few decades. The question addressed in this paper is that of the impact of these climate changes on the dynamics of debris flows since the 1950s. 319 debris flows in the Dévoluy and Ecrins massifs located in the French Alps, the triggering of which is independent of the current glacial retreat, have been analysed. In the Dévoluy a reduction in the number of debris flows was observed in the periods 1950-1975 and 1975-2000. In the Massif des Ecrins, we have observed a shift of the triggering debris flow zone toward higher elevations and a lack of significant variation in the number of debris flows. But in the Massif des Ecrins this global result masks two different trends depending on elevation. At low altitude $(<2200 \mathrm{~m})$ the number of debris flows and the frequency of debris flows less than $400 \mathrm{~m}$ in length have decreased significantly since the 1980 s whereas no significant variation was observed at high altitude $(>2200 \mathrm{~m})$. At the same time, we have observed a significant increase in the annual and seasonal temperatures for these 20 last years combined with a significant reduction in the number of freezing days. A significant increase in summer rains higher than $30 \mathrm{~mm} / \mathrm{d}$ has also been observed. In Dévoluy and at low altitude in the Massif des Ecrins, these variations can be explained by the decrease in the number of freezing days related to the increase in the temperatures, which implies a slower reconstitution of the volume of debris stored between two events. But at high altitude it is currently difficult to establish the link between the climatic change and the dynamics of the debris flows because very little is known about the two variables controlling the triggering of the debris flows, i.e., on the one hand intense precipitations and on the other hand the volume of rock debris.
\end{abstract}

\section{Introduction}

Hill slope debris flows can be defined as a rapid mass movement and are common in the Alpine environment. The geometrical and sedimentological characteristics of these fast flowing mixtures of sediment and water have been observed in a wide range of mountain environments (Van Steijn et al., 1988; Kotarba, 1989; André, 1990; Haeberli et al., 1990; Nieuwenhuijzen and Van Steijn, 1990; Luckman, 1992; Van Steijn, 1991, 1996).

At the same time laboratory measurements have enabled a better understanding of how this process operates and have provided various models (Johnson and Ro- 
dine, 1984; Coussot, 1994; Bertran and Texier, 1994; Inverson, 1997; Major, 1997). Specifically, studies of the initiation of debris flows have shown the importance of stored volumes of debris and of climatic conditions (Caine, 1980; Blijenberg, 1998). Generally, an intense rainfall event triggers this process, although debris flows have also been triggered by the sudden release of water stored under glaciers or by the breaching of a morainic dam (Evans and Clague, 1994; Antoine and Fabre, 2001) or by melting snow (Wenshou and Cunhai, 1992).

Over the last few decades an increase in temperatures and changes in the amount and frequency of rainfall have been observed (Katz and Brown, 1992; IPCC, 1996; Bryant, 1997), and depend on the altitude (Beniston et al., 1997; Diaz and Bradley, 1997). As a consequence, many researchers have considered the impact of climatic change on periglacial processes (Nyberg and Lindh, 1990; Beniston, 1994; Evans and Clague, 1994; Haeberli and Beniston, 1998) especially on the triggering of debris flows. Some studies on the relation between climate and debris flows have therefore been carried out in northern Europe (Innes, 1983, 1985a,b; Rapp, 1995; Sandersen, 1997; Nyberg and Rapp, 1998) and in the Alps (Haeberli et al., 1990; Zimmerman and Haeberli, 1992; Rebetez et al., 1997). These studies show a relationship between the triggering of debris flows and an increase in the number of intense rainfall events and/or glacier retreat and permafrost degradation due to an increase in temperatures since the middle of the 19th century.

However, research into the impact of this climatic change on debris flow frequency-magnitude or on occurrence remains insufficient. In the French Alps, for example, the only research done on this subject was in a valley located in the southern part of the French Alps (Van Steijn, 1996; Blijenberg, 1998). This work showed that activity has been high since 1980 (especially in 1987) but results do not necessarily point to a recent increase in debris flow activity. In the Dolomites, Strunk (1992) says 'there is no evidence of any trend towards an increase or a decrease in the frequency since the end of the last century'.

In the Swiss Alps, studies concerning a large number of events over a wide area focused on the year 1987 because of its exceptional character (Haeberli et al., 1990; Zimmerman and Haeberli, 1992). Rebetez et al. (1997) have observed that the frequency of large debris flows has increased since the late 1980s but unfortunately the low number of events ( 9 cases), limited geographically to the Ritigraben area, and the link between the triggering of these debris flows and the melting of permafrost, means that these observations cannot be generalised. Consequently, additional observations made from a wide sample of debris flows in other sectors of the Alps are needed to confirm or refute these preliminary predictions especially in locations not recently deglaciated.

The aim of this paper is to illustrate geomorphic variations of debris flows since the 1950s with respect to climatic change in two areas of the French Alps. This study was conducted on a large sample of debris flow deposits located in two areas, the south of Dévoluy (plateau de Bure and its neighbouring valleys) and the northern part of the Massif des Ecrins. 


\section{Area Studied}

Debris flows were selected in two areas. The first area includes the plateau de Bure and its neighbouring valleys (between $44^{\circ} 36^{\prime} \mathrm{N}$ and $44^{\circ} 49^{\prime} \mathrm{N}$ ), and is about $26 \mathrm{~km}^{2}$ in area. It is located on the south edge of the Massif du Dévoluy, which is the highest massif of the French Pre-Alps (Pic de Bure, 2709 m asl, Obiou, 2790 m asl) (Figure 1).

The sides of the plateau de Bure and the neighbouring valleys are made up of Senonian limestone which forms rock faces over $200 \mathrm{~m}$ high dominating active talus slopes (Pech, 1993, 1996) on which debris flows occur (Figure 2). These slope deposits are located between 1900 and $2400 \mathrm{~m}$ asl. Meteorological data acquired over 6 years on the plateau $\left(2700 \mathrm{~m}\right.$ asl) show that the $0^{\circ} \mathrm{C}$ isotherm is around $2500 \mathrm{~m}$ asl (Pech, 1996). At this elevation precipitation is around $2000 \mathrm{~mm} / \mathrm{y}$ of which $70 \%$ occurs as snow essentially between November and May. In contrast to other studies in the Alps (Haeberli et al., 1990; Zimmerman and Haeberli, 1992; Rebetez et al., 1997), the originality of this site is that it has not been glaciated since the last glaciation. Thus glacial recession since the end of the Little Ice Age has not affected debris flow activity. However, we cannot exclude the influence of a possible melting of the permafrost.

The second area of $28 \mathrm{~km}^{2}$ corresponds to the northern part of the Massif des Ecrins $\left(45^{\circ} 00^{\prime} \mathrm{N}, 6^{\circ} 30^{\prime} \mathrm{E}\right)$. In this area (Figure 3), 11 valleys not covered by glaciers since the Little Ice Age (according to old documents and geomorphic observations) have been studied. These valleys consist of broad steep granite walls 200-300 m above talus slopes (Figure 4), which have already been studied (Francou, 1988; Jomelli, 1997, 1999; Jomelli and Francou, 2000; Jomelli, 2002). These deposits are situated between $1600 \mathrm{~m}$ asl and $2400 \mathrm{~m}$ asl which is close to the $0^{\circ} \mathrm{C}$ mean annual isotherm.

In both areas, the debris flows studied are triggered at the base of a cliff which has been eroded by a gully, and flow on slope deposits at the base of the cliffs. Consequently the flow is only partially chenalized except where debris flow uses an old channel formed on the slope by an old debris flow.

\section{Data Sources}

\subsection{DEBRIS FLOW DOCUMENTATION}

In the Dévoluy area, debris flows were observed by combining two approaches. Aerial photographs from 1948, 1952, 1956, 1971, 1978, 1980, 1982, 1989, 1993, 1997, 1999 and 2000 were analysed. The scale of these photographs was between 1:20,000 and 1:30,000. Field observations were made every year from 1995 onwards. These two approaches were used to date debris flows. However, old documents (Office National des Forêts, Restauration des Terrains en Montagnes, Archives départementales) and dendrochronology (Shroder, 1978) were 
(a)

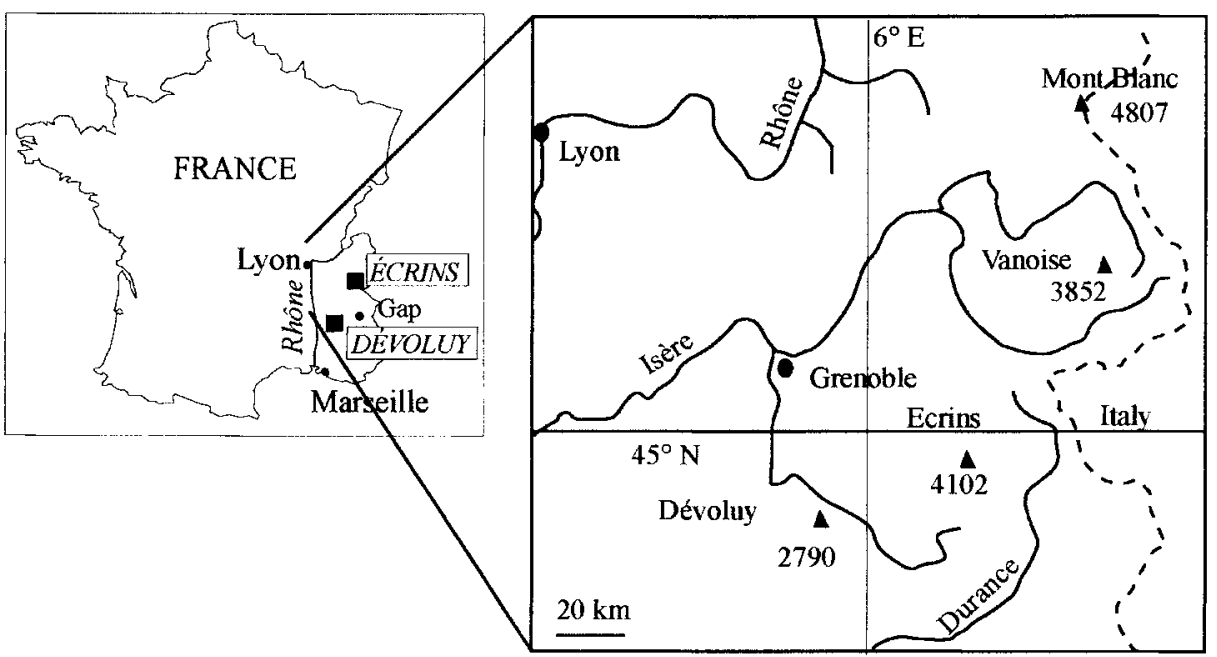

(b)

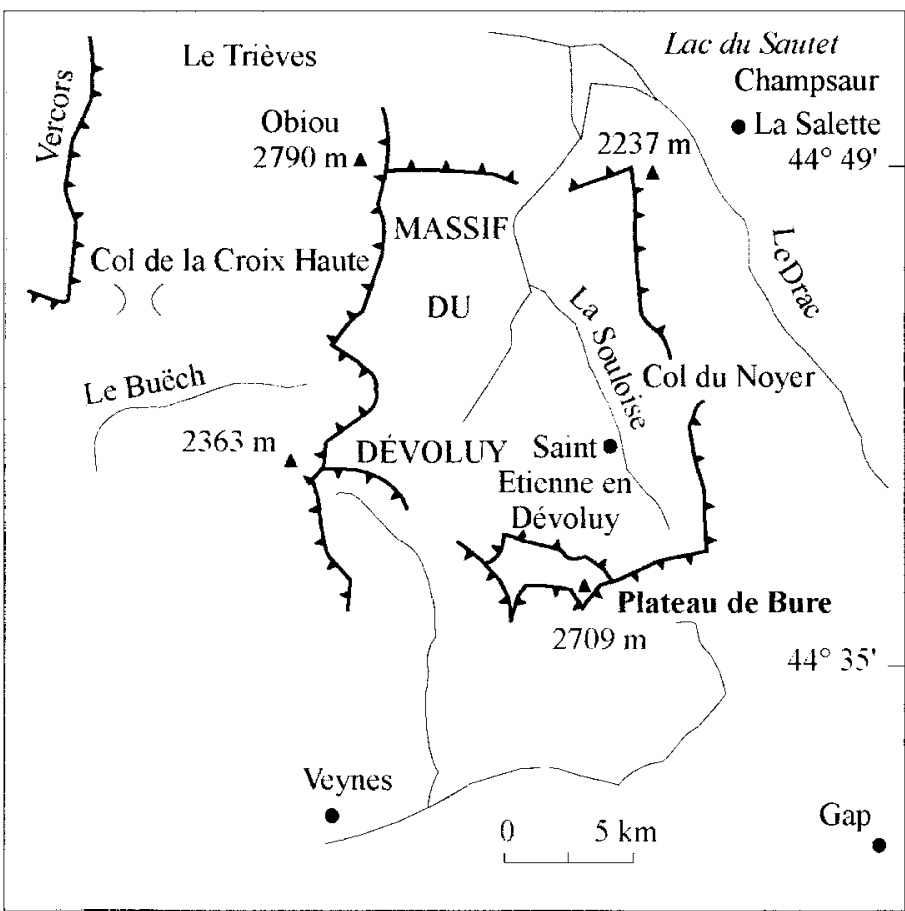

Figure 1. (a) General location map with the Massif du Dévoluy and Massif des Ecrins; (b) Detail of the Massif du Dévoluy. 


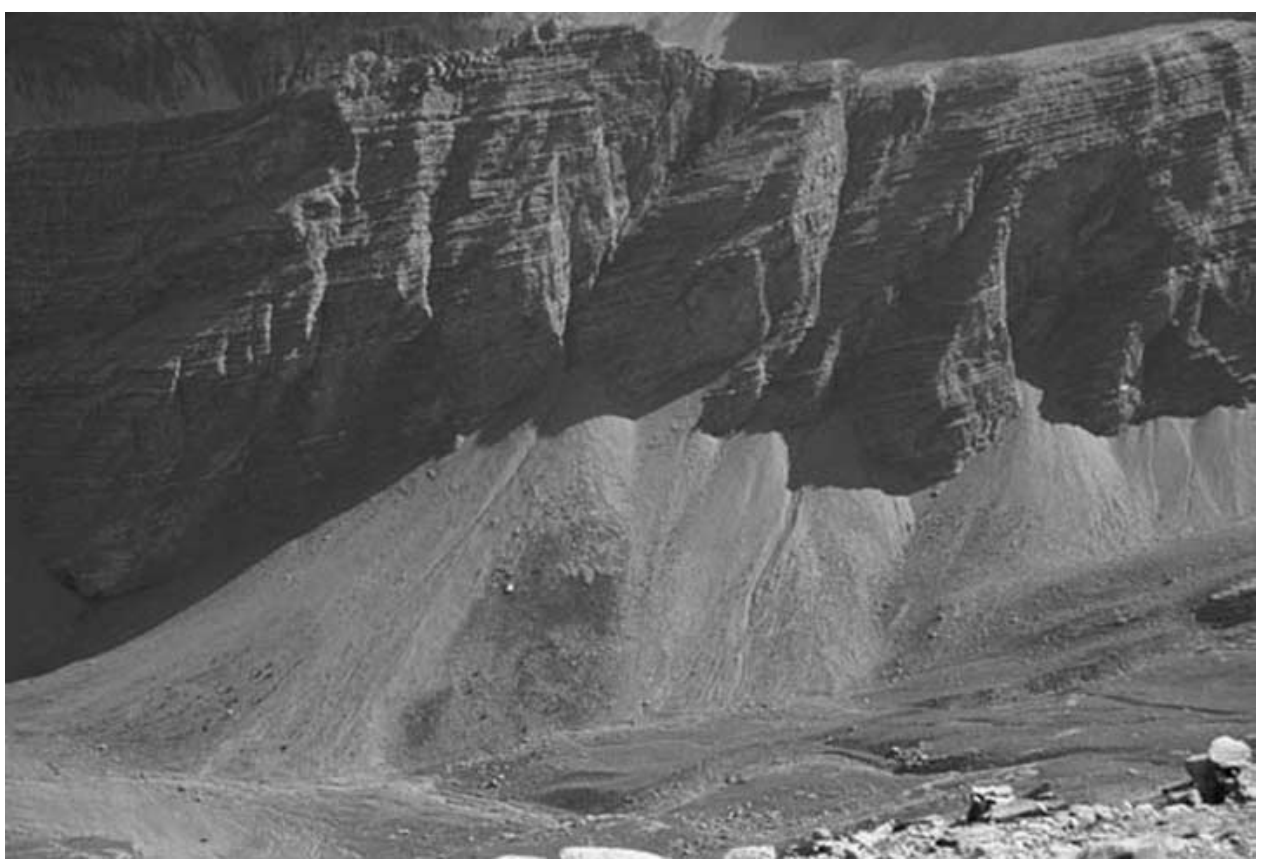

Figure 2. Debris flows in the southern part of the Dévoluy (Combe Ratin, Pic de Bure).

also used to date the debris flows triggered between two aerial photographs. In dendrochronology, we worked from scars and wood reaction of Larix decidua. Samples were processed in accordance with the classical methods of dendrogeomorphology. Debris flows predating 1951 and those that were impossible to date (13, mainly before 1975) were not taken into account in the analysis.

For the Massif des Ecrins, the same methods were used. Aerial photographs from 1952, 1960, 1967, 1971, 1974, 1981, 1986, 1989, 1994, 1996, 1999 and 2000 were analysed. Seventeen debris flows (11 before 1975) which it was impossible to date to the year and those predating 1953 were rejected. For each dated debris flow, its length was measured in the field and the minimum altitude of the starting zone was estimated from photo interpretation and field observations (accuracy $\pm 20 \mathrm{~m}$ ) (Tsao, 2000; Le Parcq, 2001; Chochillon, 2002). This minimum altitude of the starting zone corresponds in the couloir to the point from which the slope exceeds $41^{\circ}$. This value corresponds to the angle of repose of granite rock debris.

If the couloir had a regular slope but a gradient higher than $41^{\circ}$ or if, on the contrary, it presented vertical sections intersected with subhorizontal sections, the limit which was selected corresponded to the altitude of the apex of the deposit.

\subsection{METEOROLOGICAL DATA}

The criteria when choosing the meteorological stations were three in number: they had to be the closest to the study site, the highest in altitude and have been observed 


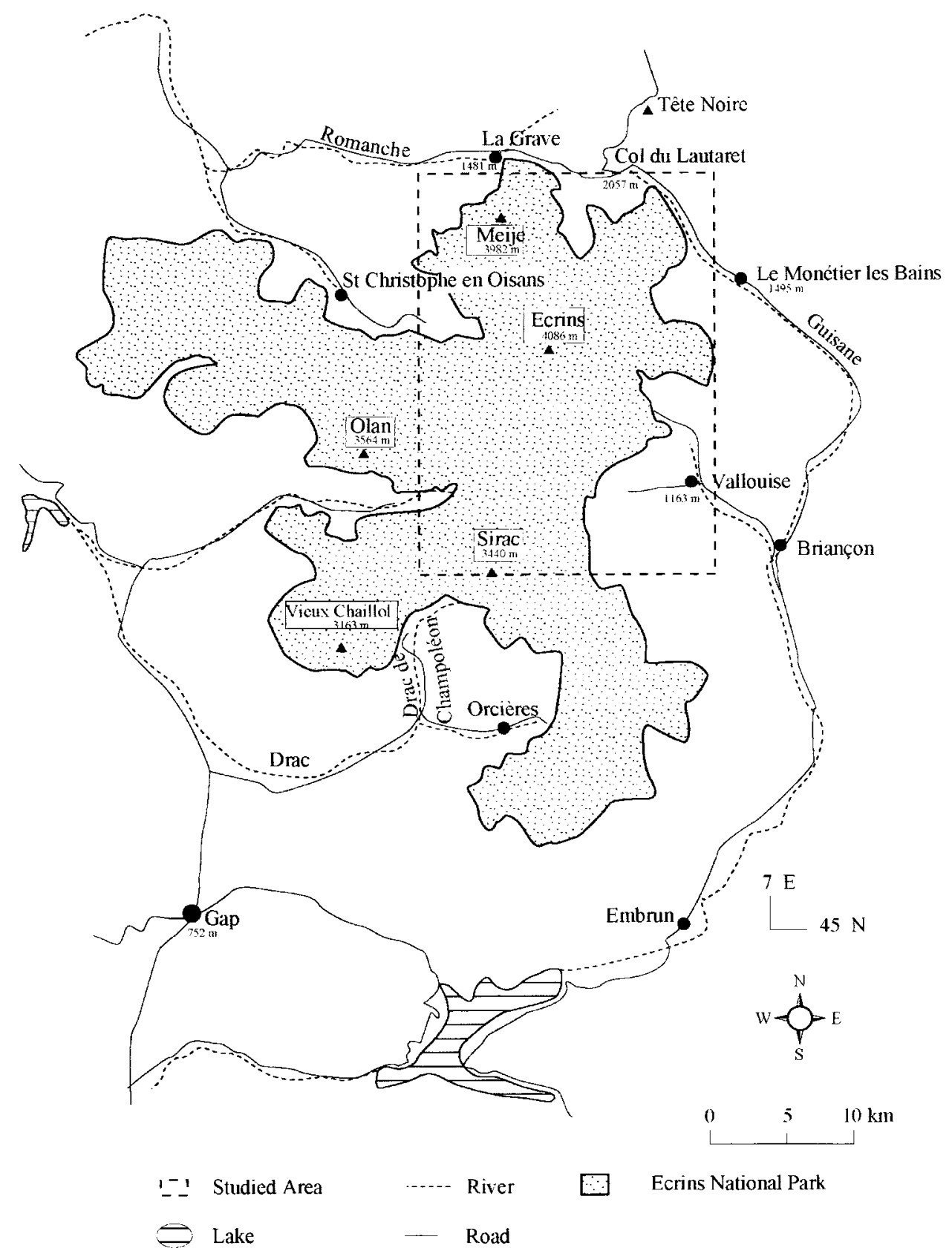

Figure 3. Location map of the Ecrins sector. 


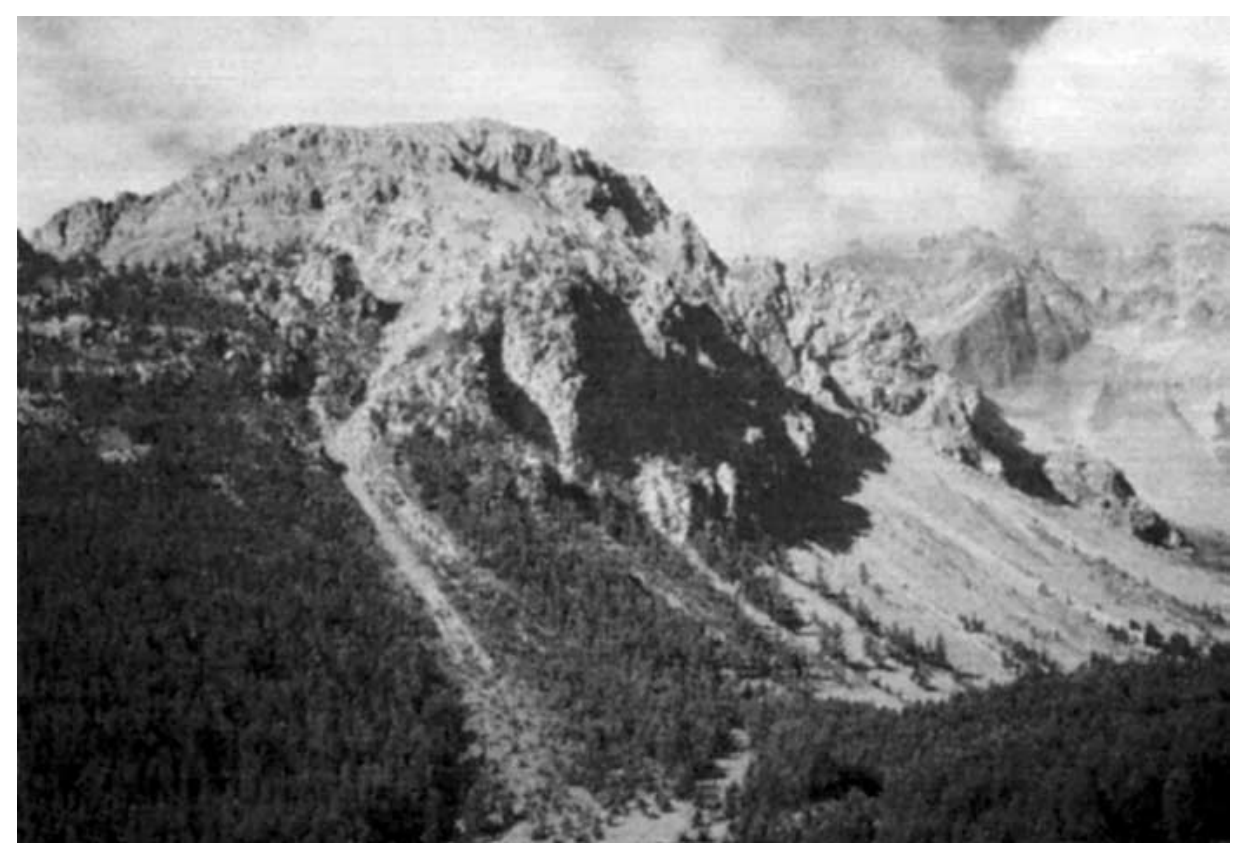

Figure 4. Northern face of the Fontenil valley on which several debris flows can be observed.

for a period of at least thirty years. In the Dévoluy area, we worked with La Salette (1770 m asl) (Figure 1) station, which provided temperature and precipitation data going back to 1965. For the Massif des Ecrins, we worked with Le Monétier-lesBains (1490 m asl) and Saint Christophe en Oisans (1570 m asl) stations, whose data go back to 1961 and 1964 respectively.

We chose to use data collected from stations covering very large areas, in order to try to document the relationship between climatic change and debris flow variations. This has been done to improve the reliability of the results because there is not necessarily a relationship between local variation of the events studied and more global climatic trends.

\subsection{WHY A REGIONAL APPROACH?}

In this analysis we have chosen to work from a sample distributed over a larger spatial area, though the link between climatic change and variation of the dynamics is indirect, since weather measurements cannot be taken on the same site. However, given the number of observations taken into account and the spatial scale considered, the results are more representative. 


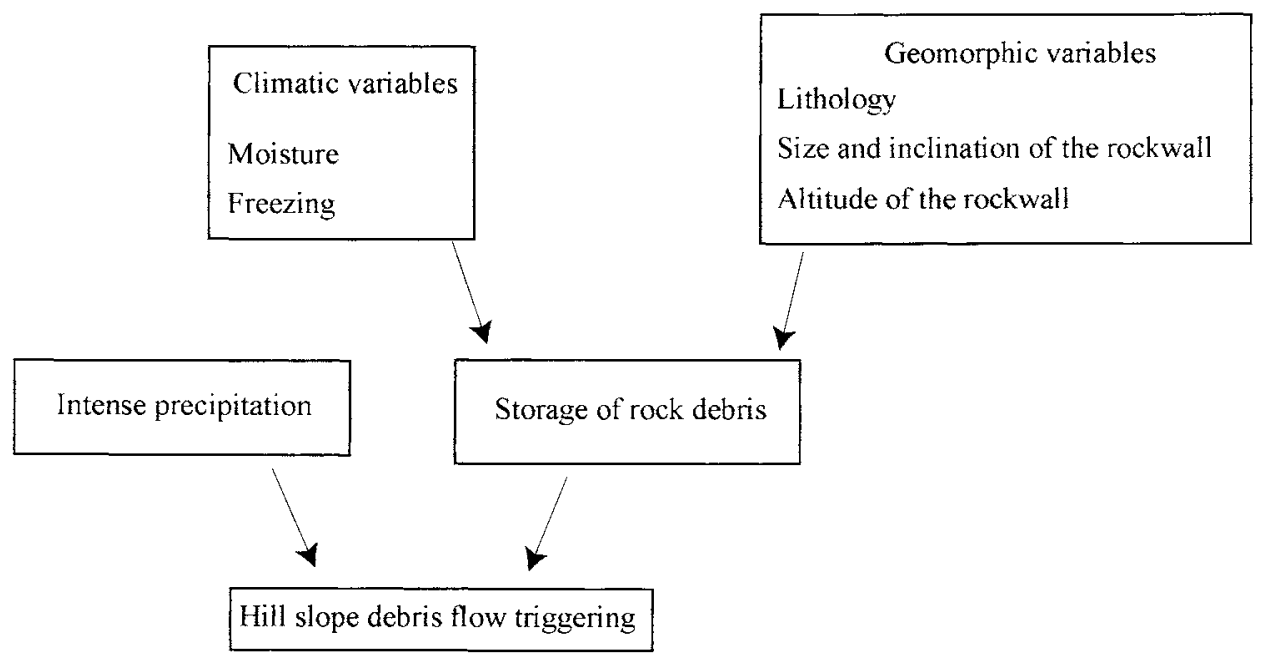

Figure 5. Factors controlling the triggering of hill slope debris flows in the French Alps.

\section{Triggering Factors in Debris Flow Occurrence}

It is well known that two conditions are needed for debris flow to be triggered (Caine, 1980; Johnson and Rodine, 1984; Van Steijn, 1996; Iverson, 1997): long duration or high intensity of heavy rainfalls and a large volume of debris (Figure 5). The relationship between debris flow triggering and the duration - intensity of rainfalls has often been studied (Zimmermann, 1990; Zimmermann and Haeberli, 1992; Blijenberg, 1998). Caine (1980) and other authors have shown that the higher the intensity the shorter the duration. Even if the importance of stored volumes of debris has been well known for a long time (Statham, 1976), few authors have studied the relationship between stored volumes of debris and debris-flow triggering (Pech and Jomelli, 2001). These volumes of debris are due either to morainic accumulations on a slope (Haeberli et al., 1990; Rickenman and Zimmermann, 1993) or to debris accumulated in a couloir or at the apex of a slope deposit (Pech and Jomelli, 2001) by frost weathering.

The importance of spatial and temporal overlap between heavy rainfall and a stored volume of rock debris has already been underlined, its absence being a possible explanation for the absence of relationship between heavy rainfall and the triggering of debris flows (Pech and Jomelli, 2001). In other words, if at year $t$ a flow is triggered, the probability of a flow being triggered at year $t+1$ will be low even if heavy rainfalls are observed because, if the stored volume is completely mobilised when the first flow is triggered, several years will a priori be necessary for it to be reconstituted.

After a flow has been triggered, the time needed for the store of rock debris to be reconstituted, when it is not related to glacial dynamics, depends on climatic and geomorphological parameters. The climatic parameters are linked to the tem- 
peratures and precipitations. Generally the rate of this type of weathering depends on the frequency of freeze - thaw alternations inside the rock-wall, their duration and their intensity (Coutard and Francou, 1989). However, fragmentation of the rock by freezing occurs only when the rock has a certain water content (Matsuoka et al., 1997). This moisture can be related to rain or the melting of the snow cover. However, the time necessary for the reconstitution of the stock also depends on lithology, contributive surface and the altitude of the rock-wall (since temperatures vary according to altitude).

We have shown (Pech and Jomelli, 2001) that a debris flow needs both heavy rainfalls and the accumulation of debris. When a debris flow occurs, no other can be triggered immediately afterwards, even if high intensity rainfall events occur, because the debris was evacuated with the first event. The reconstitution of the accumulation is a long process which depends on climatic and geomorphic parameters, especially frost activity in the cliff (Coutard and Francou, 1989; Pech and Jomelli, 2001). The rate of this type of weathering depends on rock strength and local climatic conditions such as freeze - thaw alternation intensity.

In order to better understand the relationship between these parameters and the occurrence of debris flows, we recently (Jomelli et al., 2003) used a statistical model with data collected from the Massif des Ecrins. To build this model we needed a logistic regression (Aldrich and Nelson, 1984). The dependent variable Yi is ordered and has values from 1 to $k$. The model based on cumulative probabilities is:

$$
\operatorname{Logit}\left(p_{i}\right)=f\left(\operatorname{Pr}\left(Y_{i} \leq i \mid x\right)\right)=\alpha_{i}+\beta^{\prime} x+e
$$

$f(x)$ is the logistic distribution function, where $i$ varies from 1 to $k$, the intercept $\alpha_{i}$ varies from $\alpha 1$ to $\alpha k-1, \beta^{\prime}$ is the slope coefficient and $e$ the error. The logistic distribution constrains the estimated probabilities to lie between 0 and 1 . The cumulated probability pi of the occurrence $i$ is calculated from the equation:

$$
p_{i}=\frac{e^{\operatorname{Logit}\left(p_{i}\right)}}{1+e^{\operatorname{Logit}\left(p_{i}\right)}} .
$$

This model shows a clear statistical relationship between the dynamics of debris flows and climate. Between 1961 and 2000, the probability of the occurrence was due to the cumulated number of freezing days since the last event (nfd) and the number of rainfall events greater than $30 \mathrm{~mm} /$ day (nrd) between June 15th and October 15th, with an error $(e)$.

The model is:

$$
\operatorname{Logit}\left(p_{1}\right)=-4.7236+(0.388 * \operatorname{nfd})+(0.5717 * \operatorname{nrd})+e .
$$




\section{Results}

\subsection{CLIMATIC VARIABILITY}

First of all, we studied the evolution of the annual and seasonal mean precipitations for the periods 1960-1980 and 1980-2000. No significant variation appeared from the annual data taken since 1980 , for all weather stations studied.

On a seasonal time scale, we can see at Monétier station (Figure 6) a small increase in the amounts of rainfall in spring, summer and autumn since 1961. Winter is the only season which shows a small decrease in precipitation for this period. However, these variations between 1960-1980 and the period after 1980 are not significant (Mann-Whitney test), whatever the meteorological station.

We also studied the highest daily total rainfall during the warmest period of the year. Figure 7 shows the evolution between 1964 and 2000 of the ten highest daily totals occurring each year between June 15 and October 15 at St Christophe. There would seem to be a $20 \mathrm{~mm} / \mathrm{d}$ threshold. Above $20 \mathrm{~mm} / \mathrm{d}$ no significant difference was observed over the period from 1965 to 2000 (z-test). However, above $30 \mathrm{~mm}$ the number of rain-days was observed to have increased significantly ( $z$-test) since the 1980s for the thresholds of 30 and $40 \mathrm{~mm}$ (Table I). At La Salette 13 events between 30 and $40 \mathrm{~mm} / \mathrm{d}$ occurred between 1970 and 1985, as opposed to 29 after 1985. For the more intense events, the difference was less marked and not significant, with 9 events as opposed to 11 between 40 and $50 \mathrm{~mm}$ and 9 events as opposed to 10 above $50 \mathrm{~mm} / \mathrm{d}$. These observations are in concordance with the results of meteorological analyses which concern wider areas in the Alps, such as the northern Italian Alps (Brunetti et al., 2001) or other sectors in the Alps (Rebetez et al., 1997; Frei and Schär, 2001).

Our analysis of the mean annual temperatures, which have increased since the 1980s, confirms other observations which concern the whole of the European Alps using homogenised instrumental time series (Böhm et al., 2001). Two stations (with the exception of Le Monétier station) clearly show such an increase (Table II). With ten-year mean temperatures, there is a decrease of $0.3{ }^{\circ} \mathrm{C}$ for the period $1960-1970$, followed by an increase of $0.4{ }^{\circ} \mathrm{C}$ between 1970 and 2000 .

From the seasonal data we can observe that in spring the temperatures have increased significantly ( $t$-test) since the beginning of the 1980s, (with the exception of Le Monétier station). In summer, the mean value of this increase is around $0.9^{\circ} \mathrm{C}$. The increase in temperatures in autumn $\left(0.6^{\circ} \mathrm{C}\right)$ is only significant $(t$-test) in Saint Christophe and La Salette stations. Finally, for winter period we observed a general significant increase $\left(0.7^{\circ} \mathrm{C}\right)$ concerning the periods $1960-1980$ and 1980-2000 for all the stations.

When we focus on the evolution of the number of freezing days since the 1960s, a significant decrease ( $t$-test) in the number of freezing days (around 14\%) is observed at La Salette station since the beginning of the 1980s (Figure 8) due to the increase in temperatures. Such a trend is also observed at Le Monétier (12\%) and at Saint Christophe (14\%). 

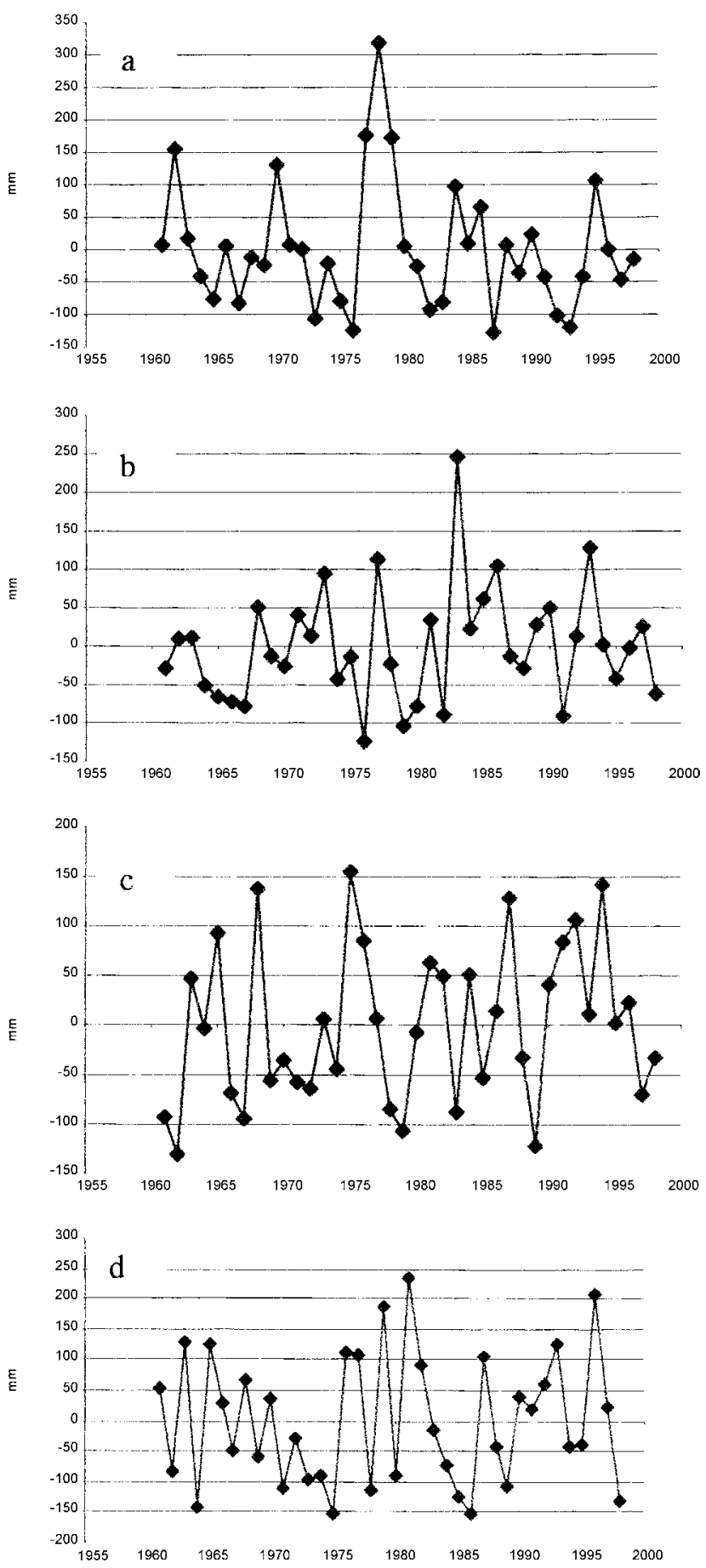

Figure 6. Deviations from the mean of precipitations at Monétier station between 1961 and 2000. (a) Winter (d, j, f); (b) Spring (m, a, m); (c) Summer, (j, j, a); (d) Autumn (s, o, n). 


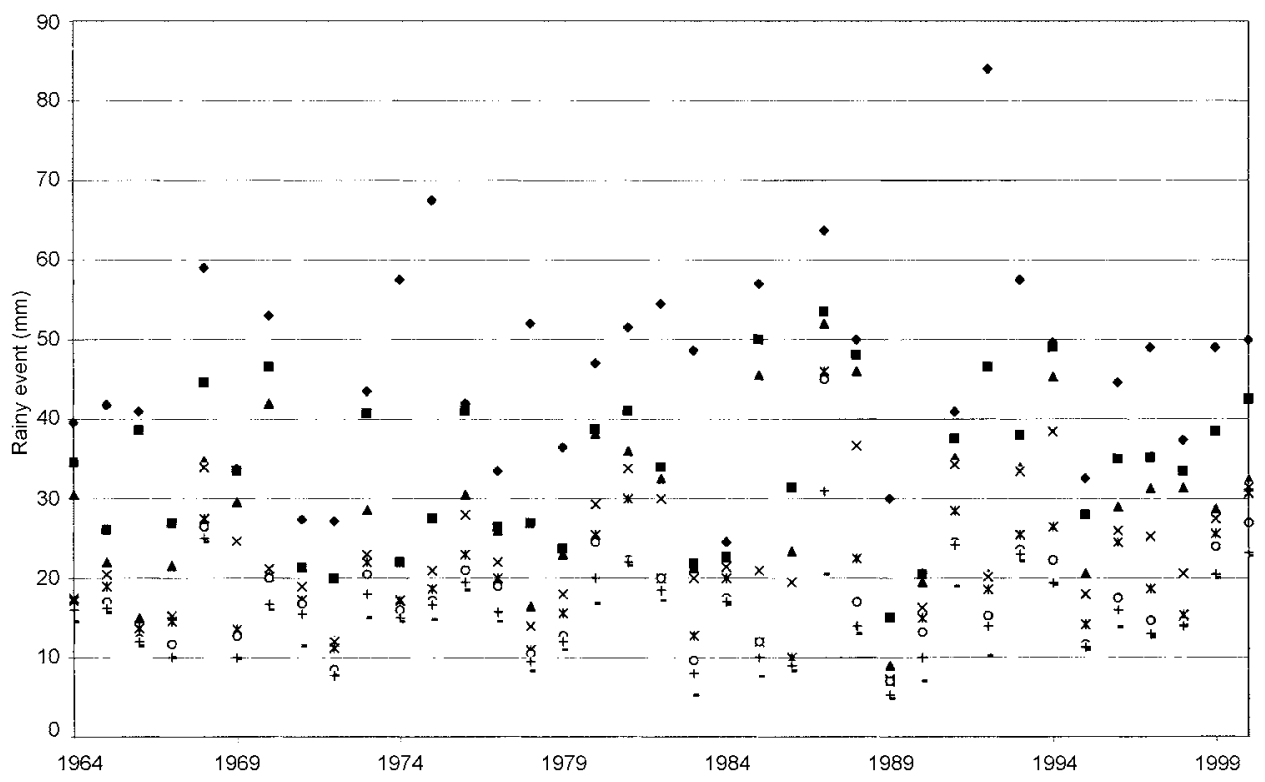

Figure 7 . The 10 most important rainy events per day occurring each year between the 15 th June and the 15th October since 1964 at St Christophe station.

Table I

$z$-Test values (bold $=$ significant)

\begin{tabular}{lrl}
\hline & & $1965-2000$ \\
\hline St Christophe & $>30 \mathrm{~mm}$ & $\mathbf{0 . 0 0 6}$ \\
& $30-39 \mathrm{~mm}$ & $\mathbf{0 . 0 1 9}$ \\
& $40-49 \mathrm{~mm}$ & $\mathbf{0 . 0 4 9}$ \\
& $>50 \mathrm{~mm}$ & 0.167 \\
& & \\
Monétier & $>30 \mathrm{~mm}$ & $\mathbf{0 . 0 2}$ \\
& $30-39 \mathrm{~mm}$ & $\mathbf{0 . 0 3}$ \\
& $40-49 \mathrm{~mm}$ & 0.67 \\
& $>50 \mathrm{~mm}$ & 0.8 \\
La Salette & $>30 \mathrm{~mm}$ & $\mathbf{0 . 0 0 1}$ \\
& $30-39 \mathrm{~mm}$ & $\mathbf{0 . 0 0 5}$ \\
& $40-49 \mathrm{~mm}$ & 0.722 \\
& $>50 \mathrm{~mm}$ & 0.835 \\
\hline
\end{tabular}


Table II

$t$-Test values (bold $=$ significant)

\begin{tabular}{llll}
\hline & $1970-1980$ & $1980-1990$ & $1965-2000$ \\
\hline St Christophe & 0.061 & 0.052 & $\mathbf{0 . 0 0 1}$ \\
Monétier & 0.368 & 0.522 & 0.163 \\
La Salette & 0.301 & 0.662 & $\mathbf{0 . 0 0 1}$ \\
\hline
\end{tabular}

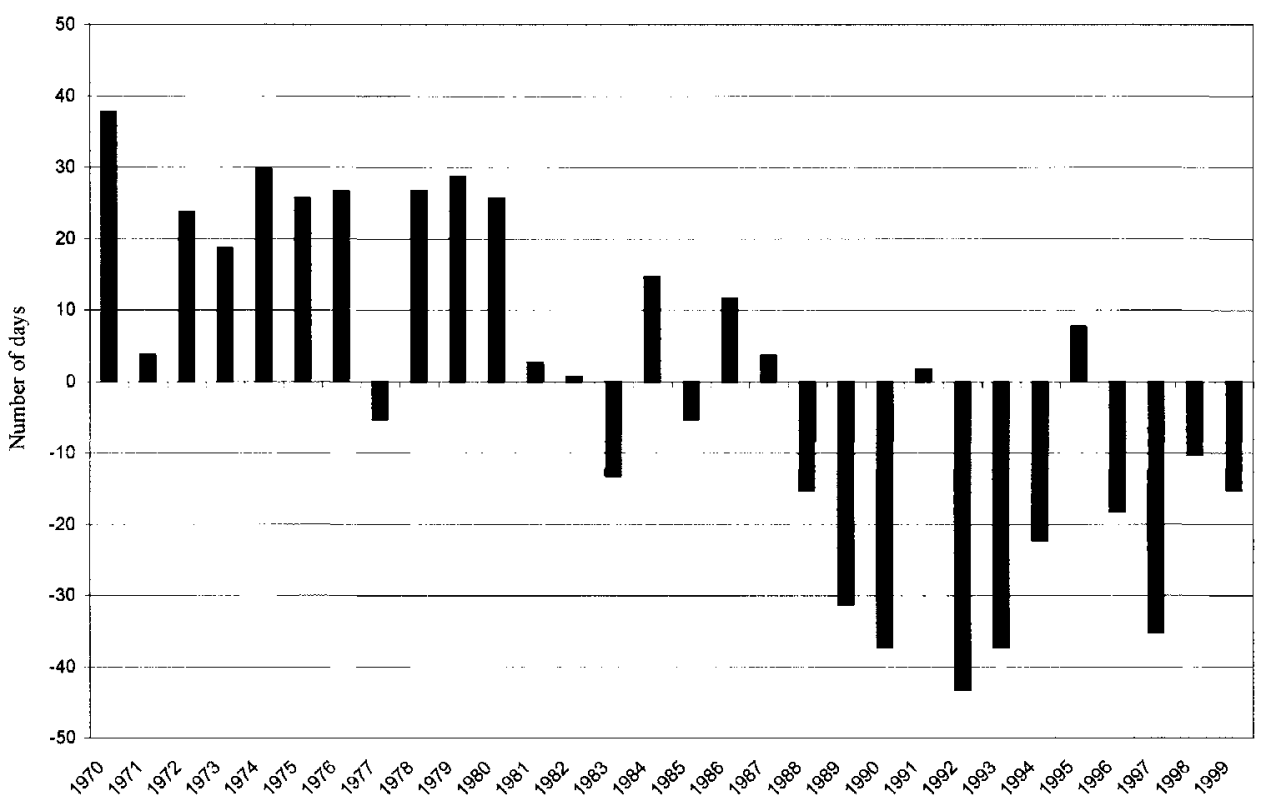

Figure 8. Deviations from the mean annual number of freezing days at La Salette station between 1970 and 2000.

To summarise, it is clear that climatic changes are attested by both a significant increase in the annual mean temperatures and a decrease in the number of freezing days. The analysis of the rainfall shows a significant increase in daily rainfall greater than $30 \mathrm{~mm}$. Consequently, if we consider the relationship between heavy rainfalls and the triggering of debris flows, the logical evolution would be an increase in the number of debris flows since the 1980s.

\subsection{VARIATIONS IN THE DYNAMICS OF DEBRIS FLOWS}

The analysis of variations in debris flow occurrence in the Dévoluy area is based on 128 events which have occurred since 1948. A significant decrease (0.048 MannWhitney test, 0.05 level) in the number of debris flows has been observed since the mid-seventies (Figure 9). 84 debris flows were triggered between 1950 and 1975 


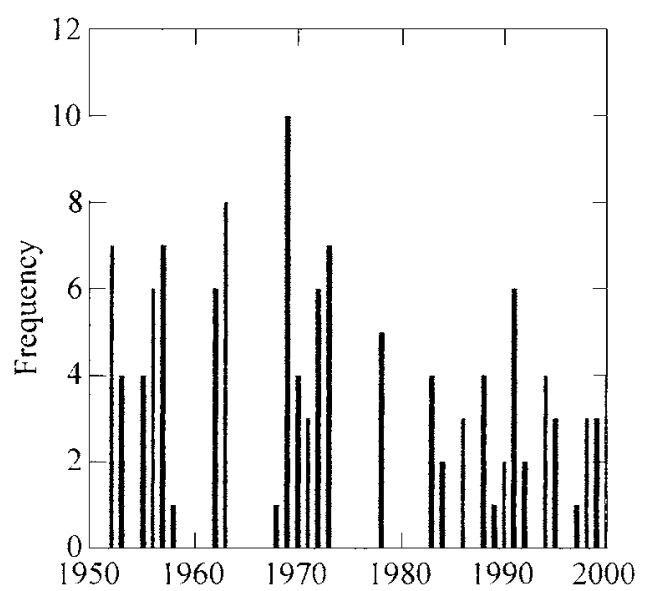

Figure 9. Frequency of debris flows in the Dévoluy sector $(N=121)$.

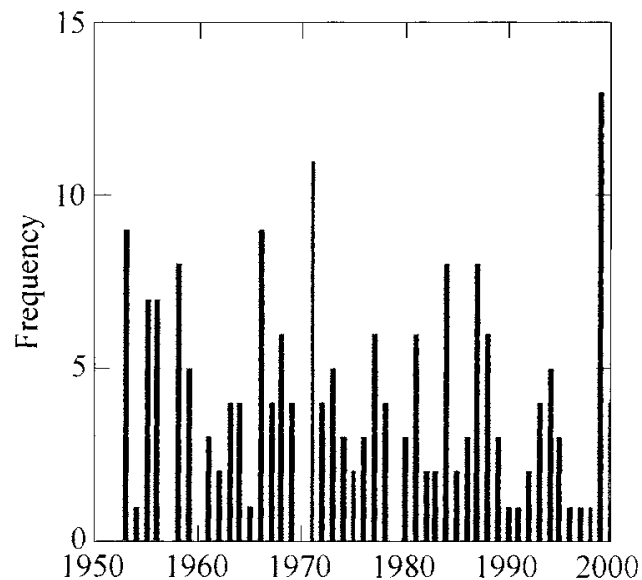

Figure 10. Frequency of debris flows in the northern part of the Massif des Ecrins $(N=219)$.

and only 48 since 1975 . If this analysis is conducted over ten-year periods, the total number of debris flows was not statistically different ( 0.05 level) between 1950 and 2000.

For the Massif des Ecrins, data analysis was based on 191 debris flows which occurred between 1953 and 2000. If we look at two comparable periods, 102 debris flows were triggered between 1953 and 1976 and only 89 since 1976. However, as shown in Figure 10, this evolution is not statistically significant.

Considering that a relationship exists between the length of debris flows and their frequency, the data have been classified here by their length. The analysis of the frequency distribution (Figure 11) shows that the modal value of the debris flows is between $200 \mathrm{~m}$ and $299 \mathrm{~m}$, and that length values under $599 \mathrm{~m}$ account for $74 \%$ of the debris flows. 

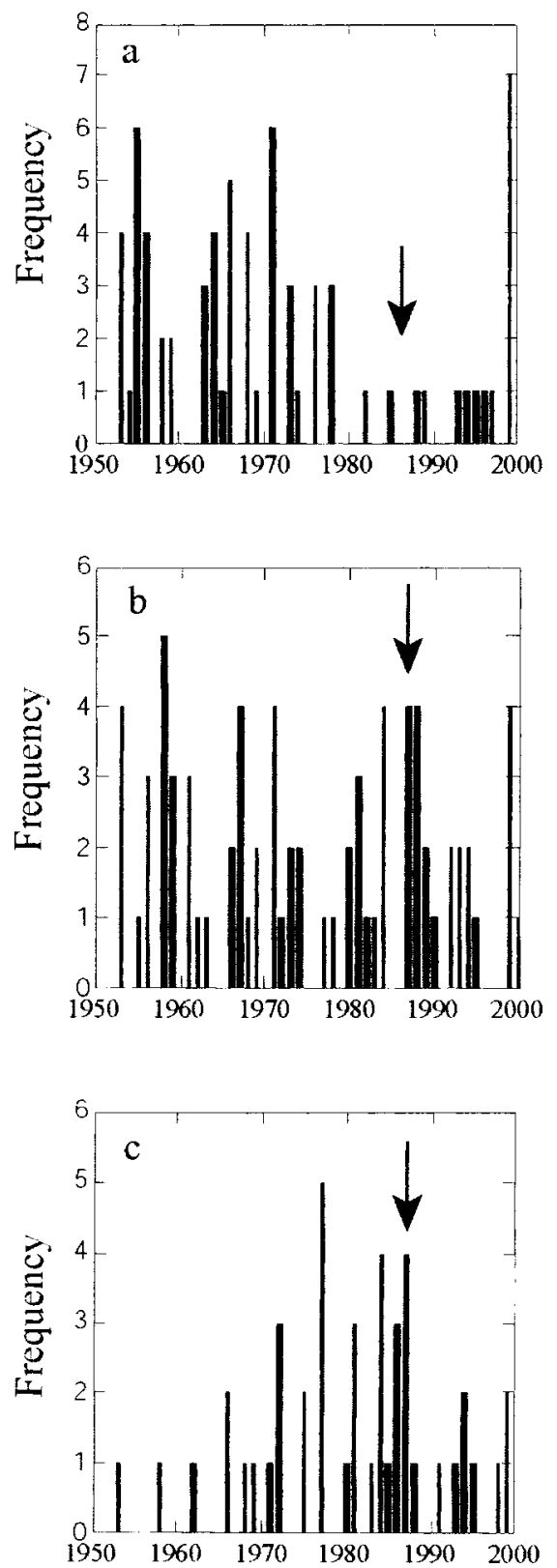

Figure 11. Frequency of debris flows in the Massif des Ecrins according to the track length of deposits. (a) $<400 \mathrm{~m}$ long $(n=70)$; (b) Between 400 and $699 \mathrm{~m}$ long $(n=75)$; (c) $>700 \mathrm{~m}$ $(n=46)$. Arrow $=1987$. 
Table III

Return period for the different debris-flow class lengths between 1952 and 2000 in the Massif des Ecrins

\begin{tabular}{|c|c|c|c|c|c|c|c|c|c|}
\hline & $\begin{array}{l}<100 \mathrm{~m} \\
(\mathrm{yr})\end{array}$ & $\begin{array}{l}100- \\
199 \mathrm{~m} \\
(\mathrm{yr})\end{array}$ & $\begin{array}{l}200- \\
299 \mathrm{~m} \\
(\mathrm{yr})\end{array}$ & $\begin{array}{l}300- \\
399 \mathrm{~m} \\
(\mathrm{yr})\end{array}$ & $\begin{array}{l}400- \\
499 \mathrm{~m} \\
(\mathrm{yr})\end{array}$ & $\begin{array}{l}500- \\
599 \mathrm{~m} \\
(\mathrm{yr})\end{array}$ & $\begin{array}{l}600- \\
699 \mathrm{~m} \\
(\mathrm{yr})\end{array}$ & $\begin{array}{l}700- \\
799 \mathrm{~m} \\
(\mathrm{yr})\end{array}$ & $\begin{array}{l}>800 \mathrm{~m} \\
(\mathrm{yr})\end{array}$ \\
\hline 1953-1975 & 5 & 3.5 & 4 & 4.4 & 6 & 4.8 & 9.5 & 18 & - \\
\hline 1976-2000 & 4.7 & 2 & 2 & 4.5 & 5 & 5 & 10 & 17 & - \\
\hline $1953-2000$ & 4.8 & 2.7 & 3 & 4.5 & 5.5 & 4.9 & 9.7 & 17.5 & $>52$ \\
\hline
\end{tabular}

A significant decrease (0.01, Mann-Whitney test) in the number of debris flows can be observed between 1953-1975 and 1976-2000 for the debris flows less than $400 \mathrm{~m}$ in length (Figure 11). On the contrary, there are no significant variations in the number of the debris flows longer than $400 \mathrm{~m}$ between these two periods (Figures 11b,c).

When taking the data over ten-year periods, the variations are hardly noticeable. There was a high activity during the 1970s but the number of debris flows is not significantly different from the other decades. Moreover, 1987 is not characterised by a great number of debris flows, unlike observations elsewhere in the Alps (Zimmermann and Haeberli, 1992; Rickenmann and Zimmermann, 1992; Van Steijn, 1996, 1999) even though the number of rainfall days greater than $30 \mathrm{~mm}$ was the highest over the 1960-2000 period (7 events).

In all the valleys studied, the mean return period, defined as the time between two events whether or not they occurred in the same system for each valley separately, was around 19.6 years. It has decreased for debris flows with lengths between 100 and $300 \mathrm{~m}$ for the periods 1953-1975 and 1976-2000 (Table III). For the other lengths, we have not observed clear significant variation between the two periods. As shown in Table III, this return period increases with length of debris flow: 4 years for debris flows less than $100 \mathrm{~m}$ in length and more than 50 years for debris flows longer than $800 \mathrm{~m}$. Moreover, we can observe that this return period is correlated with the mean elevation of debris flow triggering zones (Figure 12).

For the whole period, the minimum mean elevation of triggering zones is around $2100 \mathrm{~m}$, between a maximum at $2650 \mathrm{~m}$ and a minimum at $1650 \mathrm{~m}$. However, if we compare the distribution of the elevation of triggering zones during the two periods 1953-1975 and 1976-2000 (Figure 13), it seems that a shift has occurred towards higher elevation zones. The triggering zones lower than $2200 \mathrm{~m}$ represent less than $40 \%$ between 1976 and 2000 as opposed to more than $65 \%$ for the period 1953-1975.

Finally we studied variations in minimum altitude of the debris flow triggering zones between 1952 and 2000 for all sites of the Massif des Ecrins (Figure 14). 


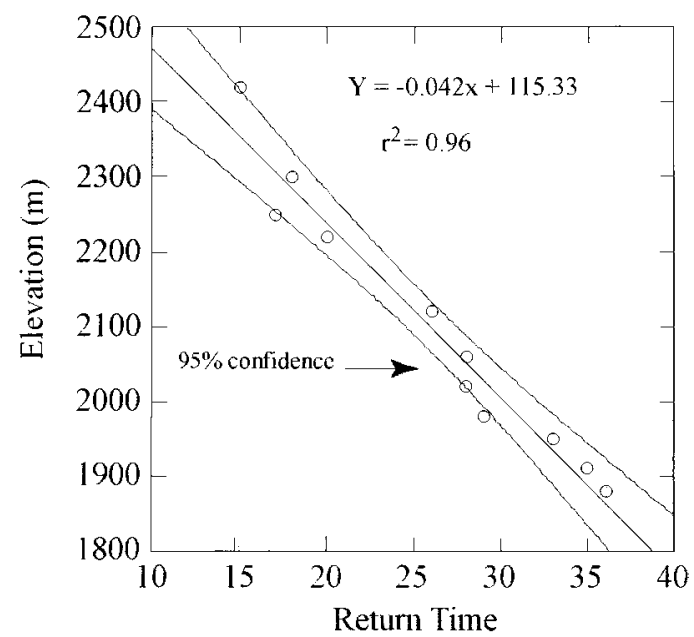

Figure 12. Mean altitude of the triggering zone of debris flows smaller than $400 \mathrm{~m}$ versus return time over the period 1952-2000 for each of the 11 valleys in the Massif des Ecrins.

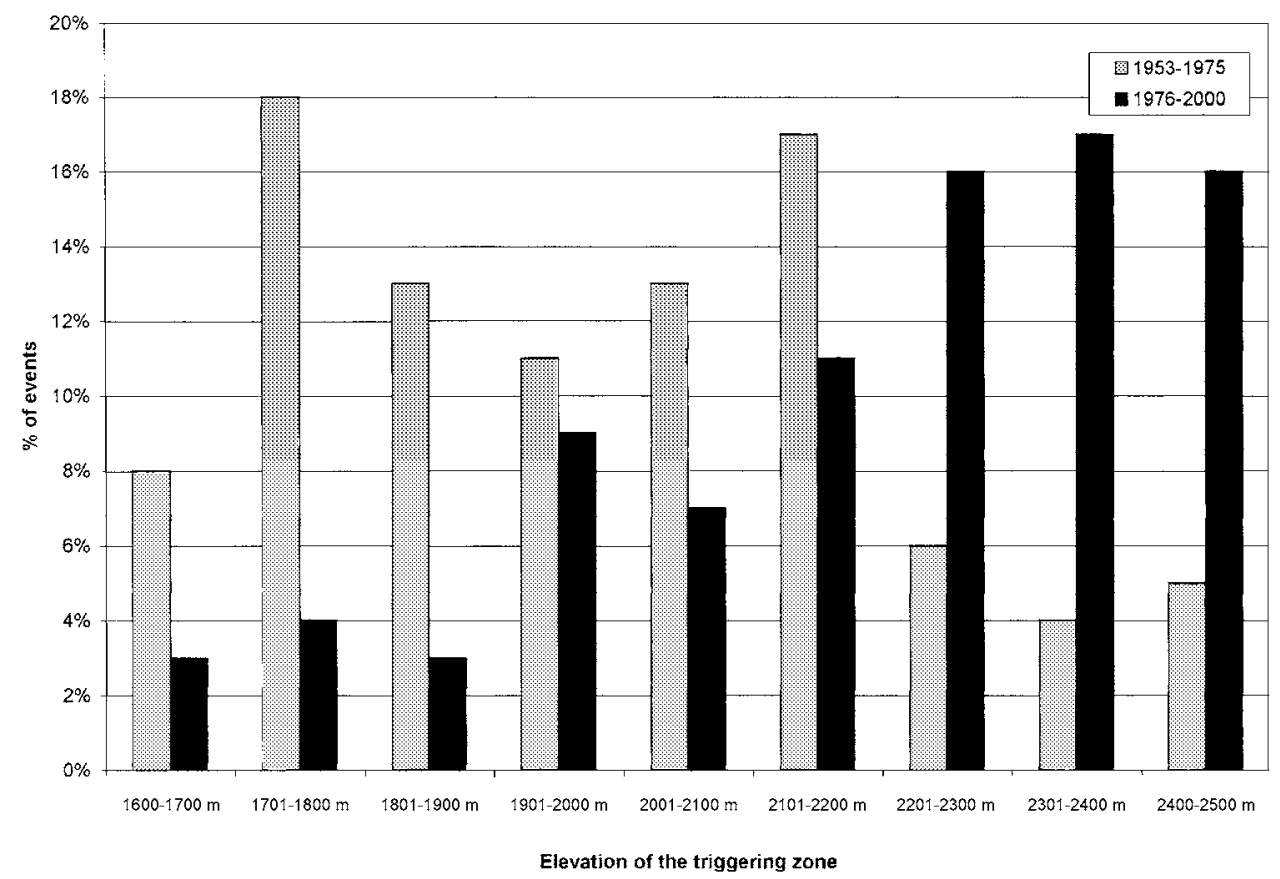

Figure 13. Number of debris flows smaller than $400 \mathrm{~m}$ between 1952 and 2000 according to the elevation of the triggering zone. 


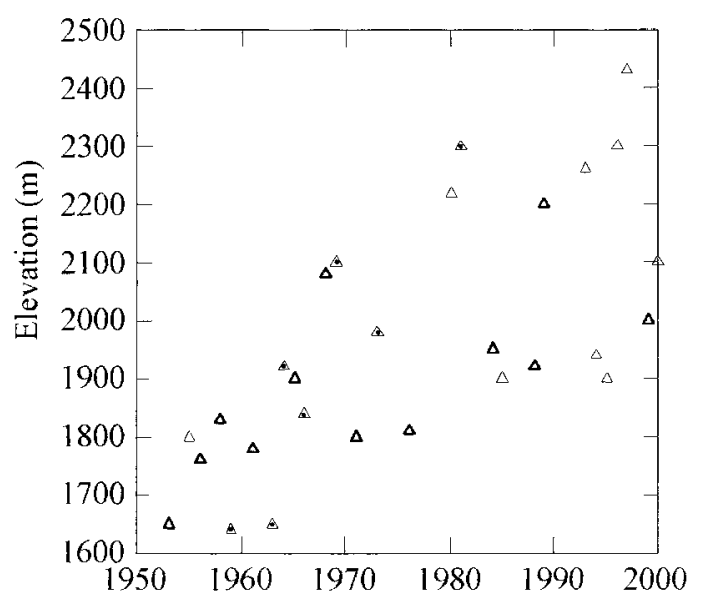

Figure 14. Lowest triggering zone altitude of debris flows between 1952 and 1999 in the Massif des Ecrins. Bold triangle $>6$ measurements; Triangle with a point $=$ between 3 and 5 measurements; Triangle $<3$ measurements.

According to our observations, minimum altitudes increased by more than $100 \mathrm{~m}$ during this period. Triggering zones lower than $1800 \mathrm{~m}$ asl have been inactive since 1976.

Finally, in the Dévoluy area a reduction in the number of debris flows has been observed since the 1980s. In the Massif des Ecrins, we have shown an upward shift in the triggering debris flow zone and a lack of significant variation in the total number of debris flows. At the same time, the frequency of debris flows under $400 \mathrm{~m}$ has decreased significantly.

\section{Discussion}

In various places in the Alps, recent studies have shown a relationship between the triggering of debris flows and the increase in the number of intense rainy events and/or in temperatures. This rise in temperatures has caused a glacial recession and the melting of the permafrost over the last few decades (Haeberli et al., 1990; Zimmerman and Haeberli, 1992; Rebetez et al., 1997). In the Dévoluy, the Massif des Ecrins and in other sites of the French Alps (Hang, 1994; Thevenon, 1999; Bocquet, 2001), it seems that signs of the recent climatic change can also be observed. This climatic change can be seen in an increase in temperatures and an increase in the number of daily rainfalls above $30 \mathrm{~mm}$ occurring in the summer.

Our analysis, based on 319 debris flows for which the triggering is not linked to glacial retreat, is characterised by variations in debris flow dynamics since the 1980s. Some are apparently in contradiction with the nature of the climatic changes observed. Why has the increase in rainfall above $30 \mathrm{~mm}$ not led to an increase in the number of debris flows? Here, we propose different explanations. 


\subsection{HOW GOOD ARE THE DATA CONCERNING DEBRIS FLOWS?}

First of all, does the number of debris flow deposits correspond to the actual number of debris flows triggered? It is indeed possible that certain low amplitude triggered flows were not listed, even though debris flows under $100 \mathrm{~m}$ in length were taken into account in the analysis protocol. As for the debris flows which follow the exact path of the channel created by a previous debris flow but are not as long, and whose frequency is sufficiently high not to be identified by the analysis of the aerial photographs or field observations, their number is difficult to evaluate but is probably low. Consequently, without excluding these two possible skews, their influence on the results remains weak and in no way explains the trend observed previously.

\subsection{THE REPRESENTATIVITY OF THE RAINFALL DATA}

It is well known that the intensity and duration of the rainfall play an important role in the triggering of debris flows (Caine, 1980; Van Steijn, 1996; Blijenberg, 1998) and that therefore the representativity of the rainfall data can be discussed. Several doubts arise concerning the extrapolation of meteorological data collected at low elevation. For example, Sevruk (1997) showed in Switzerland a clear spatial heterogeneity of the precipitations. Such a situation seems to be particularly true for our field area because heavy rainfalls, which occur in summer, are mainly due to local storms. In order to evaluate the impact of the elevation on the variations in amounts of rainfall, we compared daily data from Le Monétier with nine years of recorded data at the Tête Noire station, which is in the same valley but at a higher altitude (2030 $\mathrm{m}$ asl; Figure 3 ). The result of the comparison ( $z$-test) between data does not show significant differences in the number of days for which the rainfall is more than $30 \mathrm{~mm}$ between June 15th and October 15th during the 1976-1985 period. The number is strictly the same, with the exception of 1984 , for which there is one event with rainfalls greater than $30 \mathrm{~mm}$ at the bottom of the valley and 4 at the top. It is well known that rainfall is greater at higher altitudes than at lower ones (Gerrard, 1990; Barry, 1992). In the stations studied, 13 daily events between 30 and $40 \mathrm{~mm}$ occurred in lower areas and 14 events at higher elevation; these patterns were 5 and 10 respectively, for rainfall between 40 and $50 \mathrm{~mm}$, and 5 and 7 respectively, for rainfall above $50 \mathrm{~mm} / \mathrm{d}$. Consequently this undervaluation does not account for the absence of increase in the number of debris flows.

Moreover, it is necessary to recall the differences between the data observed on the flat surface collected by classical instruments and those which were recorded in a couloir or at the base of a wall acting as an impluvium. Francou (1988) has shown that one debris flow had been triggered on August 9th 1983, in Combe de Laurichard, but the rainfalls had been $12.8 \mathrm{~mm}$ at Le Monétier, less than $10 \mathrm{~mm}$ at Saint Christophe and $17 \mathrm{~mm}$ (in 3 hours) at Tête Noire. However because of the size of the impluvium, the author considered the event to be equivalent to a $50 \mathrm{~mm}$ runoff when deliberately taking a high infiltration rate $(50 \%)$. In addition, 
some researchers have highlighted the role of intensities lasting only a few minutes (Blijenberg, 1998) in the triggering of debris flows, but unfortunately this type of observation does not exist near the sites selected in this study. Consequently this undervaluation does not account for the absence of increase in the number of debris flows either.

\subsection{THE POSSIBLE ROLE OF ANOTHER PARAMETER}

The results show an apparent contradiction between the decrease in number and frequency of debris flows, and the increase in the number of days during which rainfall is more than $30 \mathrm{~mm}$. However, it has already been shown that the amount of rainfall may be a necessary (Caine, 1980; Johnson and Rodine, 1984; Innes, 1985b) but not sufficient factor to trigger debris flows.

The volume of stored debris at the foot of the cliff is the second factor involved in the triggering of debris flows which must be taken into account in this analysis. A decrease in this volume or in the time needed for its reconstitution may be responsible for the variation. If the cliff supplies less debris, even if heavy rainfall events remain high in number, there is no evidence that a debris flow occurs. However, for the same lithology, the volume or the rate of reconstitution of the stock depends on the frequency, intensity and duration of freezing and consequently on the temperatures.

The question is whether the increase in temperatures reduces the volume and/or rate of reconstitution of the stock. At low altitude, the stations selected showed a significant reduction in the frequency of freezing days ( $t$-test). This observed decrease in the number of freezing days may explain the decrease in debris flow frequency in the Dévoluy Massif (assuming that changes in air temperatures are high enough to provoke a change inside the rock faces which it is currently not possible to check).

In the Massif des Ecrins, we separated the debris flows whose triggering zone is below $2200 \mathrm{~m}$ from those with a higher elevation (this $2200 \mathrm{~m}$ value corresponds to the mean of all watersheds) because they did not have the same dynamics. At low elevation, we have observed a significant decrease (0.01, Mann-Whitney test) in debris flow occurrence (Figure 15a) and also in the frequency of small debris flows since the 1980s. Consequently, this decrease in occurrence and frequency is due to the decrease in the number of freezing days at low elevation. This fact may also explain the general increase in elevation of the triggering zone.

On the contrary, the number and frequency of debris flows have not changed at high altitude ( $>2200 \mathrm{~m}$ asl) (Figure 15b). Are these results in contradiction with climatic variations observed before?

We assume that it is not the case because it is still difficult to extrapolate this reduction in the number of freezing days at high altitude. Indeed, although the increase in temperatures at high altitude has clearly been shown over the last few decades by different work done on homogenized series (Beniston et al., 1997; Diaz 

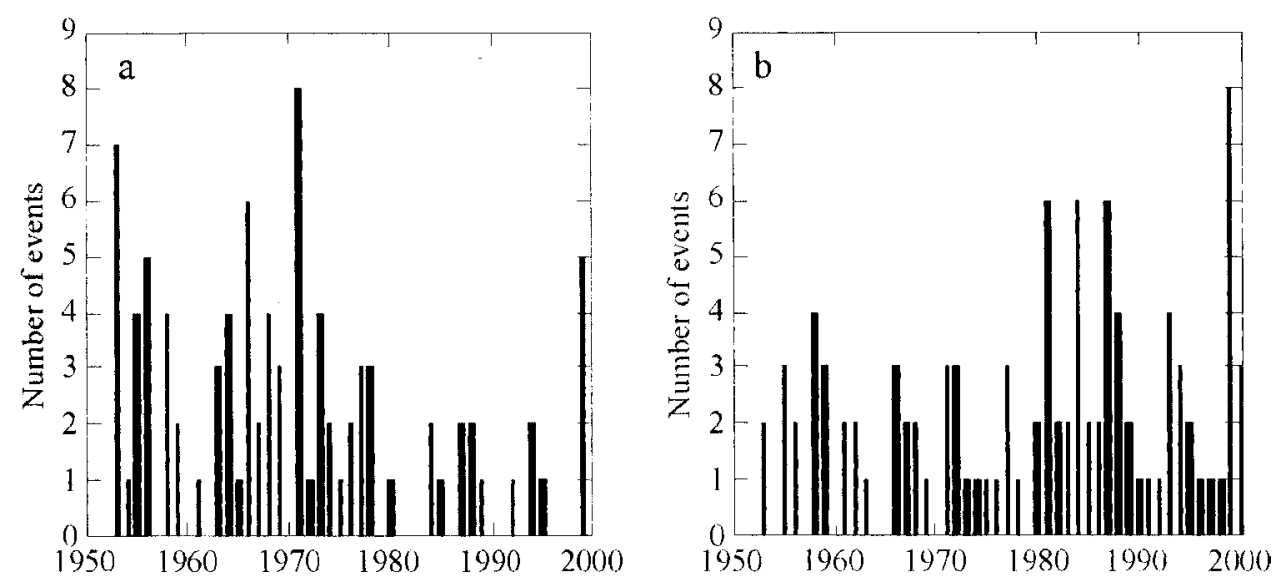

Figure 15. Frequency of debris flows in the Massif des Ecrins according to the elevation of the triggering zone. (a) Triggering under $2200 \mathrm{~m}(n=90)$; (b) Triggering above $2200 \mathrm{~m}(n=101)$.

and Bradley, 1997; Böhm et al., 2001), a detailed analysis of the amplitude of the variations in temperatures with respect to altitude is complex. For example, Beniston et al. (1997) have shown that temperature anomalies show a significant linear relationship with altitude in the Swiss Alps. Such a trend might prove that the frequency of freeze/thaw alternations and thus frost-weathering is increasing. However, Diaz and Bradley (1997) have also shown that it is clear that maximum temperature trends are lower above around $2000 \mathrm{~m}$ asl, in comparison with those at lower elevations.

Therefore, if we assume that the increase in temperatures is to be found at high altitude, the upward shift of the isotherm $0^{\circ} \mathrm{C}$ may be at the origin of increasing weathering. The temperature increase could provoke a degradation in the permafrost in rock walls as has been observed elsewhere in the Alps (Haeberli et al., 1993; Haeberli and Beniston, 1998; Wegmann et al., 1998; Imhof et al., 2000) and this trend may increase frost weathering. Moreover, the temperature increase may reduce snow cover duration and expose the high slopes to greater temperature variations.

Consequently, without local measurements it is very difficult to estimate the impact of the increase in temperatures on the frequency, intensity and duration of the freezing of the walls at high altitude and thus on the volume or rate of stored debris.

\section{Conclusion}

The aim of this study was to analyse the response of debris flow dynamics to climatic change since the 1950s in large sample areas. Two sectors of the French Alps were selected, the Plateau de Bure and neighbouring valleys $\left(20 \mathrm{~km}^{2}\right)$ and 
the eastern part of the Massif des Ecrins $\left(20 \mathrm{~km}^{2}\right)$. In the two sectors 319 debris flows have occurred since the beginning of the 1950s, the triggering of which is independent of the current glacial retreat. A climatic analysis was carried out on 3 stations located in the vicinity. This analysis has shown a significant increase in the annual and seasonal temperatures for the 20 last years combined with a significant reduction in the number of freezing days. A significant increase in summer rains above $30 \mathrm{~mm} / \mathrm{d}$ was also observed.

However, in the Dévoluy area a reduction in the number of debris flows has been observed since the 1980s. In the Massif des Ecrins, we have shown an upward shift in the triggering debris flow zone and a lack of significant variation in the number of debris flows. But this global result masks two different trends, depending on elevation.

At low altitude $(<2200 \mathrm{~m})$ the general number of debris flows and the frequency of debris flows that are less than $400 \mathrm{~m}$ length have decreased significantly whereas no significant variation has been observed at high altitude $(>2200 \mathrm{~m})$.

In the Dévoluy area and at low altitude in the Massif des Ecrins these variations can be explained by a decrease in the number of freezing days related to the increase in temperatures, which implies a slower reconstitution of the debris stored between two events. But at high altitude it is currently difficult to establish the link between the climatic change and the dynamics of the debris flows because very little is known about the two variables controlling the triggering of the debris flows, i.e., intense rainfalls and the stored volume of debris.

Until now most research has been devoted to the relationship between rainfall and triggering of debris flows. In the future a major issue will be to link this research on rainfall with a quantification of the volume of debris with respect to climatic parameters. It is necessary to acquire a better understanding of the mechanisms linking climate and the triggering of debris flows in view of future climatic forecasts (GICC, 2001) and of the risks which the debris flows represent for the populations living in the valleys.

Finally this study underlines the heterogeneous character of the response of the debris flows to the climate in the periglacial zone. The low elevation zone is explicitly sensitive to climatic variations because of its marginal position which corresponds to the altitudinal limit of distribution of the process in this area. Consequently, in the study of the relationship between climate and periglacial processes it now seems necessary to take these different sensitivities into account.

\section{Acknowledgements}

We would like to extend our thanks both to M. Rebetez and two anonymous reviewers, and to B. Francou and W. Haeberli for their constructive remarks on an earlier version of this paper. This research was carried out as part of the APN and Eclipse programme of the National Scientific Research Centre and the IMFREX 
programme of the Ministry of Research. Special thanks to C. Delamare (MeteoFrance) and G. Rovera for giving us meteorological data and H. Cortot (Parc National des Ecrins).

\section{References}

Aldrich, J. H. and Nelson, F. D.: 1984, 'Linear Probability, Logit, and Probit Models', Series, Quantitative Applications Social Sciences, 45, Sage University Paper, Thousand Oaks, p. 95.

André, M. F.: 1990, 'Frequency of Debris Flows and Slush Avalanches in Spitsbergen: A Tentative Evaluation from Lichenometry', Polish Polar Res. 11, 345-363.

Antoine, P. and Fabre, D.: 2001, Géologie, hydrologie et stabilité du système morainique du lac d'Arsine, Rapport, LIRIGM, Grenoble Université Joseph Fourier, p. 17.

Barry, R. G.: Mountain, Weather and Climate, 2nd edn, Routledge, London, p. 402.

Beniston, M. (ed.): 1994, Mountain Environments in Changing Climates, Routledge Publishing Co., London and New York, p. 492.

Beniston, M., Diaz, H. F., and Bradley, R. S.: 1997, 'Climatic Change at High Elevation Sites: An Overview', Clim. Change 36, 233-251.

Bertran, P. and Texier, J. P.: 1994, 'Structures sédimentaires d'un cône de flots de débris (Vars, Alpes françaises méridionales)', Permafrost Periglacial Processes, 5, 155-170.

Brunetti, M., Maugeri, M., and Nanni, T.: 2001, 'Changes in Daily Precipitation Distribution and in Extreme Events in the North of Italy', Int. J. Clim. 21, 861-871.

Bryant, E.: 1997, Climate, Process and Change, Cambridge Publishing, Edinburgh, p. 292.

Blijenberg, H. M.: 1998, Rolling Stones? Triggering and Frequency of Hill Slope Debris Flows in the Bachelard Valley, Southern French Alps, Ph.D. Thesis, Utrecht University, p. 233.

Bocquet, G.: 2001, 'Quelques indications sur les caractéristiques météorologiques dans le vallon du plan de l'Alpe (Haute Romanche) au cours de ces dernières années (Massif des Ecrins, France)', Revue de Géographie Alpine 3, 81-89.

Böhm, R., Auer, I., Brunetti, M., Maugeri, M., Nanni, T., and Schöner, W.: 2001, 'Regional Temperature Variability in the European Alps: 1760-1998 from Homogenized Instrumental Time Series', Int. J. Clim. 21, 1779-1801.

Caine, N.: 1980, 'The Rainfall Intensity-Duration Control of Shallow Landslides and Debris Flow', Geografiska Annaler 62A, 23-28.

Chochillon, C.: 2002, Fréquence des coulées de débris depuis le Petit Age Glaciaire dans le massif des Ecrins (Alpes françaises du Sud), Master thesis (unpub.), p. 113.

Coussot, P.: 1994, 'Rhéologie des laves torrentielles', La Houille Blanche 3, 32-37.

Coutard, J. P. and Francou, B.: 1989, 'Rock Temperature Measurements in Two Alpine Environments: Implications for Frost Shattering', Arc. Alp. Res. 21, 399-416.

Diaz, H. F. and Bradley, R. S.: 1997, 'Temperature Variations during the Last Century at High Elevation Sites', Clim. Change 36, 253-279.

Evans, S. G. and Clague, J. J.: 1994, 'Recent Climatic Change and Catastrophic Geomorphic Processes in Mountain Environments', Geomorphology 10, 107-128.

Eybergen, F. A. and Imeson, A. C.: 1989, 'Geomorphic Processes and Climatic Change', Catena 16, 307-319.

Francou, B.: 1988, L'éboulisation en haute montagne Andes et Alpes, Éditec, Caen, p. 696.

Frei, C. and Schär, C.: 2001, 'Detection Probability of Trends in Rare Events: Theory and Application to Heavy Precipitation in the Alpine Region', J. Climate 14, 1568-1584.

Gerrard, A. J.: 1990, Mountain Environments, Belhaven Press, London, p. 317. 
Hang, R.: 1994, La variation spatio-temporelle des précipitations et des températures au cours des dernières décennies dans les Alpes françaises du Nord, Master Thesis (Unpubl.), Grenoble 1, p. 133.

Haeberli, W., Rickenmann, D., and Zimmerman, M.: 1990, 'Investigation of 1987 Debris Flows in the Swiss Alps: General Concept and Geophysical Soundings', in Hydrology in Mountainous Regions. II Artificial Reservoirs; Water and Slopes, Proceedings of two Lausanne Symposia, August 1990, IAHS Publication 194, pp. 303-310.

Haeberli, W., Guodong, C., Gorbunov, A. P., and Harris, S. A.: 1993, 'Mountain Permafrost and Climatic Change', Permafrost Periglacial Processes 4, 165-174.

Haeberli, W. and Beniston, M.: 1998, 'Climate Change and its Impacts on Glaciers and Permafrost in the Alps', Ambio 27, 258-265.

Imhof, M., Pierrehumbert, G., Haeberli, W., and Kienholz, H.: 2000, 'Permafrost Investigation in the Schilthorn Massif, Bernese Alps, Switzerland', Permafrost Periglacial Processes 11, 189-206.

Innes, J. L.: 1983, 'Lichenometric Dating of Debris Flow Deposits in the Scottish Highlands', Earth Surface Processes Landforms 8, 579-588.

Innes, J. L.: 1985a, 'Lichenometric Dating of Debris Flow Deposits on Alpine Colluvial Fans in Southerwest Norway', Earth Surface Processes Landforms 10, 519-524.

Innes, J. L.: 1985b, 'Magnitude-Frequency Relations of Debris Flows in Northwest Europe', Geografiska Annaler 67A, 23-32.

IPCC: 1996, Houghton, J. T., Meira Filho, L. G., Callander, B. A., Harris, N., Kattenberg, A., and Maskell, K. (eds.), Climatic Change 1995: The Science of Climate Change, Cambridge University Press, Cambridge, p. 572.

Iverson, R.: 1997, 'The Physics of Debris Flows', Rev. Geophys. 35, 245-296.

Johnson, A. and Rodine, J. R.: 1984, 'Debris Flow', in Brunsden, D. and Prior, D. B. (eds.), Slope Instability, Wiley, pp. 257-361.

Jomelli, V.: 1997, Géodynamique des dépôts d'avalanche: analyses morphométriques et sédimentologiques, Ph.D. thesis, University Paris VII, p. 252.

Jomelli, V.: 1999, 'Caractéristiques morphosedimentaires des dépôts d'avalanches en haute montagne alpine; variations spatio-temporelles de leur mise en place depuis le Petit Age Glaciaire', Géographie Physique et Quaternaire 53 (2), 199-209.

Jomelli, V.: 2002, Impacts du Petit Age de Glace sur les versants soumis aux processus nivopériglaciaires et aux mutations du pastoralisme: L'exemples des Hautes vallées de l'Oisan (Massif des Ecrins, Alpes françaises, Programme de Recherche CNRS APN, p. 122.

Jomelli, V. and Francou, B.: 2000, 'Comparing Characteristics of Rockfall Talus and Snow Avalanche Landforms in an Alpine Environment Using a New Methodological Approach', Geomorphology 35, 181-192.

Jomelli, V., Chochillon, C., Brunstein, D., and Pech, P.: 2003, 'Hillslope Debris Flows Frequency since the Beginning of the 20th Century in the Massif des Ecrins (French Alps)', in Rickenmann and Chen (eds.), Debris Flows Hazards Mitigation: Mechanics, Prediction and Assessment, Millpress, Rotterdam, pp. 127-137.

Katz, R. W. and Brown, B. G.: 1992, 'Extreme Events in a Changing Climate: Variability is More Important than Averages', Clim. Change 21, 289-302.

Kotarba, A.: 1989, 'On the Age of Debris Flows in the Tatra Mountains', Studia Geomorphologica Carpatho-Baltanica 23, 139-152.

Le Parcq, V.: 2001, Géomorphologie des coulées de débris dans le massif des Ecrins (Alpes françaises), Master Thesis (Unpubl.), Université Paris 1, p. 116.

Luckman, B.: 1992, 'Debris Flows and Snow Avalanche Landforms in the Lairig Ghru Cairngorm Mountains, Scotland', Geografisca Annaler 74A, 109-121.

Major, J. J.: 1997, 'Depositional Processes in Large-Scale Debris Flow Experiments', J. Geology 105, 345-368. 
Matsuoka, N., Hirakawa, K., Wanatabe, T., and Moriwaki, K.: 1997, 'Monitoring of Periglacial Slope Processes in the Swiss Alps: The First Two Years of Frost Shattering, Heave and Creep', Permafrost Periglacial Processes 2, 155-177.

Nieuwenhuijzen, M. E. and Van Steijn, H.: 1990, 'Alpine Debris Flows and their Sedimentary Properties. A Case study from the French Alps', Permafrost Periglacial Processes 1, 111-128.

Nyberg, R. and Lindh, L.: 1990, 'Geomorphic Features as Indicators of Climatic Fluctuations in a Periglacial Environment, Northern Sweden', Geografiska Annaler 72A, 203-210.

Nyberg, R. and Rapp, A.: 1998, 'Extreme Erosional Events and Natural Hazards in Scandinavian Mountains', Ambio 27, 292-299.

Pech, P.: 1993, 'Méthode d'analyses pour la modélisation de dépôts de pente en haute montagne', Premières Rencontres Théo Quant., Besançon, CNRS, pp. 107-111.

Pech, P.: 1996, 'Mesures de la cryoreptation sur le plateau de Bure $(2600 \mathrm{~m})$ dans le massif du Dévoluy (Hautes Alpes, France)', Géomorphologie: Relief, Processus, Environnement 4, 37-60.

Pech, P. and Jomelli, V.: 2001, 'Rôle du cône apical dans le déclenchement des coulées de débris alpines du massif du Dévoluy, Hautes-Alpes, France', Géographie Physique et Quaternaire 1, 47-61.

Rapp, A.: 1995, 'Case Studies of Geoprocesses and Environmental Change in Mountains of Northern Sweden', Geografiska Annaler 77A, 189-196.

Rebetez, M., Lugon, R., and Baeriswyl, P. A.: 1997, 'Climatic Change and Debris Flows in High Mountain Regions: The Case Study of the Ritigraben Torrent (Swiss Alps)', Clim. Change 36, 371-389.

Rickenmann, D. and Zimmermann, M.: 1993, 'The 1987 Debris Flow in Switzerland: Documentation and Analysis', Geomorphology 8, 175-189.

Sandersen, F.: 1997, 'The Influence of Meteorological Factors on the Initiation of Debris Flows in Norway', European Paleoclimate and Man 12, 321-332.

Sevruk, B.: 1997, 'Regional Dependency of Precipitation-Altitude Relationship in the Swiss Alps', Clim. Change 36, 355-369.

Statham, I.: 1976, 'Debris Flows on Vegetated Screes in the Black Mountain, Ecarmarthenshire', Earth Surface Processes Landforms 1, 173-180.

Stunk, H.: 1992, 'Reconstructing Debris Flow Frequency in the Southern Alps Back AD 1500 Using Dendrogeomorphological Analysis', Erosion, Debris Flow and Environment in Mountain Regions, Proceedings of the Chengdu Symposium, IAHS Publication 209, 299-306.

Thevenon, O.: 1999, Les changements climatiques récents en montagne: l'exemple du massif de l'Oisans, Master Thesis (Unpubl.), Grenoble, p. 117.

Tsao, C.: 2000, Reconstitution diachronique des phases d'activité morphogéniques sur des versants de haute montagne (massif des Ecrins, Alpes françaises du Sud), Master thesis, (Unpubl.), University Paris 1, p. 171.

Van Steijn, H.: 1991, 'Frequency of Hill Slope Debris Flows in Part of the French Alps', Bull. Geomorphol. 19, 83-90.

Van Steijn, H.: 1996, 'Debris Flow Magnitude-Frequency Relationships for Mountainous Regions of Central and Northwest Europe', Geomorphology 15, 259-273.

Van Steijn, H.: 1999, 'Frequency of Hillslope Debris Flows in the Bachelard Valley (French Alps)', in Panizza, M., Soldati., M., Bertacchini, M., Van Asch, W., and Malmusi, S. (eds.) Programme in Geomorphology, London, pp. 15-24.

Van Steijn, H., De Ruig, J., and Hoozemans, F.: 1988, 'Morphological and Mecanical Aspects of Debris Flows in Parts of the French Alps', Zeitschrift für Geomorphologie 32, 143-161.

Wegmann, M., Gudmundsson, H., and Haeberli, W.: 1998: 'Permafrost Changes in Rock Walls and the Retreat of Alpine Glaciers: A Thermal Modelling Approach', Permafrost Periglacial Processes 9, 23-33. 
Wenshou, W. and Cunhai, G.: 1992, 'Studies of Ice-Snow Melt Debris Flows in the Western Tian Shan Mountains, China', Erosion, Debris Flows and Environment in Mountain Regions, Proceedings of the Chengdu Symposium, July 1992, IAHS Publication, 209, 329-336.

Zimmerman, M.: 1990, 'Debris Flows 1987 in Switzerland: Geomorphological and Meteorological Aspects', Proceedings of two Lausanne Symposia, August 1990, IAHS Publication 194, 387393.

Zimmerman, M. and Haeberli, W.: 1992, 'Climatic Change and Debris Flow Activity in High Mountains Areas. A Case Study in the Swiss Alps', Catena (suppl.) 22, 59-72.

(Received 30 April 2002; in revised form 12 September 2003) 